\title{
The Relationship between Passengers' Satisfaction of Urban Road Transport Services and Their Sense of Belonging
}

\author{
Pezhman Alborzi (Corresponding author) \\ Department of Engineering Administration, Payame Noor University, Tehran, Iran \\ E-mail: pejmanalborzi@gmail.com
}

Received: May 21, 2021 Accepted: July 3, 2021 Published: August 10, 2021

doi:10.5296/emsd.v10i3.18919 URL: https://doi.org/10.5296/emsd.v10i3.18919

\begin{abstract}
Passengers' satisfaction of urban road transportation services has been widely researched over the past few decades. However, no study has been conducted to analyze the relationship of the passengers' satisfaction of regular taxi and bus transport services with an external psychological factor. To this end, 100 passengers were randomly recruited to participate in this study. The participants were required to complete three questionnaires to assess their level of belonging and their satisfaction of regular taxi and bus transport services as two prominent urban road transport services. The questionnaire of sense of belonging had 12 items rated on a 5-point Likert Scale. The responses also were rated from "strongly disagree" to "strongly agree". The respondents were requested to grade 1 to 10 an 18-travel-attribute survey to assess their satisfaction of urban road transport services. The results indicated that passengers were not satisfied with urban road transport services; however, their satisfaction with regular taxi was higher in comparison with bus transport services. The findings also revealed that there was a significant correlation between the passengers' level of belonging and their satisfaction of public transport services.
\end{abstract}

Keywords: Satisfaction, Urban road, Transport services, Belonging

\section{Introduction}

Transportation system is highly important because enhances in transportation system can have a positive effect on land development (Deng \& Nelson, 2010). Deng and Nelson further stated that top quality of public transport system can widely develop the accessibility of its catchment area by shortening time. According to Dubé, Des Rosiers, Thériault, \& Dib (2011), public transport plays a key role in society and urban environment: it increases access to work places and service infrastructure and simultaneously, diminishes expenses of travel. 
Road transport has formed a considerable part of individuals' daily activities and it is the principal mode of transport (Nguyen, 2019). According to Ali (2010), transport is essential for the survival of the modern society. An effective and useful system of transport can highly contribute to the development of the human in a broader perspective.

A fundamental characteristic of a modern society is its preoccupation with promoting supportable manner of transport to substitute the excessive use of the private car in most urban areas (Dell'Olio, Ibeas, \& Cecín, 2010). Public transport, by definition, signify the act or the means of conveying a great number of people en masse, as opposed to transfer in individual vehicles taking very few people at a time. Regular taxi and bus has long been recognized as legal and conventional public transport option (Paronda, Regidor \& Napalang, 2016).

Satisfaction, as a key issue in transportation system, has been widely investigated (e.g., Aidoo, Agyemang, Monkah, \& Afukaar, 2013; Alvarez \& Domingo, 2018; Nguyen, 2019; Rose \& Henser, 2018). In a study to analyze the relationship between the passengers' attitudes and their satisfaction with regular taxi, Alvarez and Domingo (2018) found a significant relationship between passengers' attitude and their satisfaction towards regular taxis. Moreover, Aidoo et al. (2013) argued that bus traffic can highly affect the passenger's satisfaction with public transport service.

So, due to the significant role of public transport in people's life, passengers' satisfaction relating to transportation needs to be fully studied from different dimensions. Different factors such as time, route, schedule of activities, and the number of employees and their behaviour to passenger have noticeable impact on the passengers' satisfaction (Lai \& Chen, 2011). One extrinsic influential factor in people's satisfaction with public transport might be the amount of peoples' sense of belonging because sense of belonging is considered as the key dimensions of citizenship (Painter, 2013).

Being a member of a community and being part of a collective "we" can promote act of working together for a shared goal (Painter, 2013). Sense of belonging can demonstrate an aspect of favorable outcomes such as social inclusion/exclusion, social cohesion, and well-being. On the other side, people lack of belonging within a context can be considered as feeling of not being included and being rejected (Hall, 2009).

The term sense of belonging is defined by the American Heritage Dictionary as 'acceptance as a natural member or part' (2009). Further, belonging, which commonly is related to connectedness, attachment, membership and relatedness, is widely considered as individual sense of being connected to and cared for by others (Ryan, 1995; La Guardia, Ryan, Couchman, \& Deci, 2000). So, a strong sense of belonging yields a variety of physical and psychological benefits (D’Eloia \& Price, 2018; Milner \& Kelly, 2009; Pitonyak, 2010).

A positive sense of belonging embraces perceptions of warmth, closeness, caring, and support (D’Eloia \& Price, 2018; Eccles \& Gootman, 2002) and may arouse positive emotions encompassing happiness and joy when admirably fulfilled (Fajans, 2006). Numerous authors discussed that belonging is a basic need of the human, and that individual understanding of 
belonging can bring about both negative and positive effects (Baumeister \& Leary, 1995; Deci \& Ryan, 2000). Strong sense of belonging can bring high levels of meaning in people lives (Lambert et al., 2013).

Most of the open literatures on the public transportation were focused mainly on the passengers' satisfaction with service quality. In addition to these primary data, systematic studies on the psychological matters are still needed for better understanding of passengers' satisfaction. So this paper examines the relationship between people sense of belonging and their satisfaction of public transport.

So the current paper seeks to address the following questions:

1) Is there a significant difference between the passengers' satisfaction of regular taxi and public bus transport services?

2) Is there a significant relationship between passengers' belonging level and their satisfaction of public bus transport services?

3) Is there a significant relationship between passengers' belonging level and their satisfaction of regular taxi transport services?

The remaining part of this paper is organized as follows: Section 2 describes the approach of data collection, and methods employed in this paper to analyze the data. The empirical results and discussion are presented in Section 3. The section 4 provides the concluding remarks.

\section{Methodology}

Three questionnaires were administered among public transport users in Gorgan in order to gauge their general sense of belonging and their satisfaction with the services provided. Gorgan is the capital of Golestan province in Iran with the population of approximately 350,000. 100 bus and regular taxi passengers on working days were randomly selected to complete the questionnaires. Buses and taxis were selected because they were two prominent types of city transportation types in Gorgan.

The survey consisted of three parts; the first part contains general questions about gender, age, and occupation. The second section measured passengers' general sense of belonging by using Lambert et al.'s (2013) scale included 12 items rated on a 5-point Likert Scale. Responses were rated from "strongly disagree" to "strongly agree". A sample statement reads, "There are places I can go where I feel like I belong" Cronbach's alpha $(\alpha=0.78)$ denoted good internal consistency. The third and fourth sections are composed of 18 travel attributes from Eboli and Mazzulla (2015) questionnaire. The survey was based on factors concerning cleanliness, safety, information, personnel, and main and additional services. In order to rate satisfaction, the respondents were requested to grade 1 to 10 with each item on a scale. 1 is the least satisfied, and 10 is the most satisfied. The reliability of the survey which was calculated by Cronbach's Alpha was 0.75 .

The data were analyzed in SPSS 16. Thereafter, a descriptive analysis, paired-sample t-test, and Pearson-correlation were applied to address the research questions. 


\section{Empirical Results and Discussion}

In order to answer the first and second research questions, the descriptive statistics for public bus and regular taxi transport services are detailed in Table 1. From the analysis, the means for public bus and regular taxi transport services were 4.17 and 4.41 , respectively. The passengers' satisfaction with regular taxi was higher in comparison with public bus transport services.

Table 1. Descriptive Statistics of Passengers' Satisfaction of Bus and Taxi Transport Services and their Level of Belonging

\begin{tabular}{|l|l|l|l|}
\hline & Mean & Std. Deviation & $\mathrm{N}$ \\
\hline Bus & 4.17 & .789 & 100 \\
\hline Taxi & 4.41 & .685 & 100 \\
\hline Belonging & 2.85 & .550 & 100 \\
\hline
\end{tabular}

A paired sample t-test in Table 2 found this difference to be significant, $t(99)=3.22, p<0.002$. Together this suggests that passengers are more satisfied with regular taxi transport services.

Table 2. Paired Sample Test of Passengers' Satisfaction of Bus and Taxi Transport Services

\begin{tabular}{|l|l|l|l|l|l|l|l|l|l|}
\hline \multicolumn{2}{|c|}{} & \multicolumn{3}{|l|}{ Paired Differences } & t & df & $\begin{array}{l}\text { Sig. } \\
\text { (2-tailed) }\end{array}$ \\
\cline { 3 - 6 } \multicolumn{2}{|c|}{} & Mean & $\begin{array}{l}\text { Std. } \\
\text { Deviation }\end{array}$ & $\begin{array}{l}\text { Std. Error } \\
\text { Mean }\end{array}$ & $\begin{array}{l}\text { 95\% Confidence Interval } \\
\text { of the Difference }\end{array}$ & & \\
\cline { 4 - 7 } & & & & Lower & Upper & & \\
\hline Pair 1 & Taxi - Bus & .240 & .743 & .074 & .092 & .387 & 3.228 & 99 & .002 \\
\hline
\end{tabular}

The findings showed that despite the important role that road transports play in any urban area, their services are often insufficient to meet demand and this finding is in agreement with other papers studying passengers' satisfaction of urban road travels (Chen \& Lai, 2011; Friman, 2010). According to Dubé et al. (2011), public transport enhances access to work places and service foundations and simultaneously, decreases travel expenses, so, it owns a social role in the urban environment.

To keep and attract more road passengers, public bus and taxi transport must have top service quality to address higher number of passengers' needs and satisfy them. Increases in passenger satisfaction will result in more use of the system, new customers, and more positive public image. To achieve these purposes, reliable and useful methods are required to recognize the determinants of service quality from customer perceptions (Nwachukwu, 2014).

Passengers' dissatisfaction might discourage them to continue using public transport (Friman, Edvardsson, \& Garling, 2001; Friman \& Garling 2001) and consequently, this will not be appropriate for the survival of the modern society because an efficient transportation system can highly plays a part in human development in a wider perspective. 


\section{\لMacrothink}

The findings also showed that regular taxi brings more satisfaction for passengers which is in agreement with Ackaradejruangsri's (2015) results. Cleanliness, safety, main and additional services, simplicity, and time are among the factors affecting the passengers' higher satisfaction with regular taxis. This finding is in agreement with Ackaradejruangsri's (2015) findings which showed that prompt ride, sure ride, safe ride, and comfortable ride are among the factors that affect the passengers' satisfaction. It also supports Lai and Chen's (2011) idea suggesting that the possible factors might affect the passengers' opinion might be time, stopovers, the number of employees and their attitude, route, and service to passenger.

Pearson product moment correlation coefficient (r) was used to answer the third and fourth research questions (see Table 3). There was a positive and significant correlation between the passengers' belonging and bus transport services $(\rho=.222, p<.026)$. A positive and significant correlation was also found between passengers' belonging and regular taxi transport services $(\rho=.198, \mathrm{p}<.048)$.

Table 3. Pearson Correlations of the Passengers' Satisfaction of Bus and Taxi Transport Services with their Level of Belonging

\begin{tabular}{|l|l|l|l|}
\hline & & Taxi & Bus \\
\hline Belonging & Pearson Correlation & $.198^{*}$ & $.222^{*}$ \\
\cline { 2 - 4 } & Sig. (2-tailed) & .048 & .026 \\
\cline { 2 - 4 } & $\mathrm{N}$ & 100 & 100 \\
\hline
\end{tabular}

To the best of author's knowledge, the current research is the first paper that analyze the relationship of an external factor, that is, sense of belonging as a psychological factor with the passengers' sense of satisfaction because belonging will affect their overall well-being. A positive sense of belonging includes perceptions of warmth, closeness, caring, and support (Eccles \& Gootman, 2002) and if they are appropriately satisfied, they may result in a diversity of positive emotions including happiness and joy (Fajans, 2006).

Sense of belonging is also an indicator of valuable broad societal outcomes such as social inclusion/exclusion, well-being, social cohesion, social capital, and nationhood (Painter, 2013). Therefore, by addressing the passengers' sense of belonging, we can affect their satisfaction.

\section{Conclusion}

This study evaluated passengers' satisfaction of urban road system of transport (i.e. bus and regular taxi). This research differs from the prior public transport satisfaction because it analyzes the relationship of the passengers' satisfaction with an external psychological factor. The findings provided evidence that the passengers were not satisfied with their road public transport. Although their satisfaction with regular taxi was higher than public bus transport services. Additionally, no significant relationship was found between passengers' satisfaction and their level of belonging.

The significance of this study was to provide help for those who are in transportation charge 
to enhance the passengers' satisfaction by considering psychological factors. It is recommended that further research be undertaken to design a questionnaire to evaluate the passengers' belonging of the use of public transportation system and to analyze the effective methods to enhance their belonging to the public system of transport and consequently their satisfaction.

\section{References}

Ackaradejruangsri, P. (2015). Insights on Grab Taxi: An alternative ride service in Thailand. Review of Integrative Business Economics Research, 4(3), 49-61. [Online] Available: http://sibresearch.org/uploads/2/7/9/9/2799227/riber_b15-062_49-61.pdf

Aidoo, E. N., Agyemang, W., Monkah, J. E., \& Afukaar, F. K. (2013). Passenger's satisfaction with public bus transport services in Ghana: a case study of Kumasi-Accraroute. Theoretical and Empirical Researches in Urban Management, 8(2), 33-44.

Ali, A. N. (2010). An assessment of the quality of intraurban bus services in the city of Enugu, Enugu State, Nigeria. Theoretical and Empirical Researches in Urban Management, 5(15), 74-91.

Alvarez, D. L., \& Domingo, R. (2018). Understanding Commuters'Attitudes and Satisfaction on the Attributes of Regular Taxis and TNVS in Metro Manila. pp. 403.

Baumeister, R. F., \& Leary, M. R. (1995). The Need to Belong: Desire for Interpersonal Attachments as a Fundamental Human Motivation. Psychological Bulletin, 117(3), 497-529. https://doi.org/10.1037/0033-2909.117.3.497

Chen, C.-F., \& Lai, W.-T. (2011). Behavioral Intentions of Public Transit Passengers - The Roles of Service Quality, Perceived value, Satisfaction and Involvement. Transport Policy, 18, 318-325. https://doi.org/10.1016/j.tranpol.2010.09.003

D'Eloia, M. H., \& Price, P. (2018). Sense of belonging: is inclusion the answer? Sport in Society, 21(1), 91-105. https://doi.org/10.1080/17430437.2016.1225819

Deci, E. L., \& Ryan, R. M. (2000). The 'What' and 'Why' of Goal Pursuits: Human Needs and the Self-determination of Behavior. Psychological Inquiry, 11(4), 227-268. https://doi.org/10.1207/S15327965PLI1104_01

Dell'Olio, L., Ibeas, A., \& Cecín, P. (2010). Modelling user perception of bus transit quality. Transport Policy, 17(6), 388-397. https://doi.org/10.1016/j.tranpol.2010.04.006

Deng, T., \& Nelson, J. D. (2010). The impact of bus rapid transit on land development: A case study of Beijing, China. World Academy of Science, Engineering and Technology, 66(2010), 1196-1206.

Dubé, J., Des Rosiers, F., Thériault, M., \& Dib, P. (2011). Economic impact of a supply change in mass transit in urban areas: a Canadian example. Transportation Research Part A: Policy and Practice, 45(1), 46-62. https://doi.org/10.1016/j.tra.2010.09.002

Eboli, L., \& Mazzulla, G. (2015). Relationships between rail passengers' satisfaction and 
service quality: a framework for identifying key service factors. Public Transport, 7(2), 185-201. https://doi.org/10.1007/s12469-014-0096-x

Eccles, J., \& Gootman, J. (2002). Community Programs to Promote Youth Development. Washington, DC: National Academy Press.

Fajans, J. (2006). Autonomy and Relatedness: Emotions and the Tension between Individuality and Sociality. Critique of Anthropology, 26(1), 103-119.

https://doi.org/10.1177/0308275X06061486

Friman, M. (2010). Affective Dimensions of the Waiting Experience. Transportation Research Part F, 13, 197-205. https://doi.org/10.1016/j.trf.2010.04.006

Friman, M., \& Garling, T. (2001). Frequency of negative critical incidents and satisfaction with public transport services. Journal of Retailing and Customer Services, 8(2), 105-114. https://doi.org/10.1016/S0969-6989(00)00004-7

Friman, M., Edvardsson, B., \& Garling, T. (2001). Frequency of negative critical incidents and satisfaction with public transport services. Journal of Retailing and Customer Services, 8(2), 95-104. https://doi.org/10.1016/S0969-6989(00)00003-5

Hall, S. A. (2009). The Social Inclusion of Young Adults with Intellectual Disabilities: A Phenomenology of Their Experiences. Journal of Ethnographic and Qualitative Research, 4, 24-40.

Houghton, M. (2009). American Heritage Dictionary of the English Language (4th ed.). New York.

La Guardia, J. G., Ryan, R. M., Couchman, C. E., \& Deci, E. L. (2000). Within-person Variation in Security of Attachment: A Self-determination Theory Perspective on Attachment, Need Fulfillment, and Well-being. Journal of Personality and Social Psychology, 79(3), 367-384. https://doi.org/10.1037/0022-3514.79.3.367

Lai, W. T., \& Chen, C. F. (2011). Behavioral intentions of public transit passengers-The roles of service quality, perceived value, satisfaction and involvement. Transport policy, 18(2), 318-325. https://doi.org/10.1016/j.tranpol.2010.09.003

Lambert, N. M., Stillman, T. F., Hicks, J. A., Kamble, S., Baumeister, R. F., \& Fincham, F. D. (2013). To belong is to matter: Sense of belonging enhances meaning in life. Personality and Social Psychology Bulletin, 39(11), 1418-1427. https://doi.org/10.1177/0146167213499186

Milner, P., \& Kelly, B. (2009). Community Participation and Inclusion: People with Disabilitites Defining Their Place. Disability and Society, 24(1), 47-62.

https://doi.org/10.1080/09687590802535410

Nguyen, X. P. (2019). The bus transportation issue and people satisfaction with public transport in Ho Chi Minh city. Journal of Mechanical Engineering Research and Developments, 42(1), 10-16. https://doi.org/10.26480/jmerd.01.2019.10.16

Nwachukwu, A. A. (2014). Assessment of passenger satisfaction with intra-city public bus 


\section{Macrothink \\ Environmental Management and Sustainable Development \\ ISSN 2164-7682 2021, Vol. 10, No. 3}

transport services in Abuja, Nigeria. Journal of Public Transportation, 17(1), 5.

https://doi.org/10.5038/2375-0901.17.1.5

Painter, C. V. (2013). Sense of belonging: literature review. Ottawa: Citizenship and Immigration Canada. [Online] Available:

https://www.Canada.ca/content/dam/ircc/migration/ircc/english/pdf/research-stats/r48a-2012b elonging-eng.pdf.

Paronda, A. G. A., Regidor, J. R. F., \& Napalang, M. S. G. (2016). Comparative analysis of transportation network companies (TNCs) and conventional taxi services in Metro Manila. National Center for Transportation Studies. [Online] Available:

http://ncts.upd.edu.ph/tssp/wp-content/uploads/2016/08/Paronda-et-al.pdf

Pitonyak, D. (2010). The Importance of Belonging. [Online] Available:

http://www.dimagine.com/Belonging.pdf.

Rose, J. M., \& Hensher, D. A. (2012). Demand for taxi and hire Car Services in Melbourne, Victoria. Report prepared for Victorian Taxi Industry Inquiry.

Ryan, R. M. (1995). Psychological Needs and the Facilitation of Integrative Processes. Journal of Personality, 63(3), 397-427. https://doi.org/10.1111/j.1467-6494.1995.tb00501.x

\section{Copyright Disclaimer}

Copyright for this article is retained by the author(s), with first publication rights granted to the journal.

This is an open-access article distributed under the terms and conditions of the Creative Commons Attribution license (http://creativecommons.org/licenses/by/4.0/). 